\title{
Effect of different diets on the hepatopancreatic proteomes of Chinese mitten crab, Eriocheir sinensis
}

\section{Xiaowen Chen}

Shanghhai Ocean Universitu

\section{Xin Hou}

Shanghai Ocean Unversity

\section{Zhihua Li}

Shanghai Ocean University

\section{Deyin Lu}

Shanghai Ocean Unicersity

\section{Jun Wang}

Shanghai Ocean University

Chenghui Wang ( $\nabla$ wangch@shou.edu.cn )

Shanghai Ocean University https://orcid.org/0000-0002-6523-7610

\section{Research}

Keywords: proteomics, Eriocheir sinensis, feed type, growth, immunity

Posted Date: February 12th, 2021

DOl: https://doi.org/10.21203/rs.3.rs-134005/v2

License: (c) (i) This work is licensed under a Creative Commons Attribution 4.0 International License. Read Full License 


\section{Abstract}

Background: Aquatic plants and freshwater snails are important natural food sources of Eriocheir sinensis, which play important roles in the growth and development of $E$. sinensis. However, research on how aquatic plants and freshwater snails affect the growth and development of $E$. sinensis remains scant.

Methods: The effects of the two kinds of natural food sources on the growth and development of $E$. sinensis were studied by determining the hepatopancreatic proteomes of three groups, namely, E. sinensis fed with aquatic plants combined with freshwater snails (group A), E. sinensis fed with aquatic plants only (group B), and E. sinensis fed with freshwater snails only (group C), using tandem mass tag technology.

Results: A total of 110 differentially expressed proteins between groups A and B were identified, among which 78 were up-regulated and 32 were down-regulated in group A. Meanwhile, nine proteins were upregulated, and 14 proteins were down-regulated in group $A$ relative to those in group $C$. The proteins related to molting and growth such as cryptocyanin and cuticle protein CBM were up-regulated in group A compared with group B. The immunity-related proteins, such as mannosyl-oligosaccharide glucosidase and glutathione peroxidase, that were differentially expressed between groups $A$ and $C$, were up-regulated in group A.

Conclusion: The results indicated that freshwater snails might promote the growth and development of $E$. sinensis to a certain extent, and aquatic plants might play an important role in the immunity of $E$. sinensis. Our study provides a theoretical basis for the practice of "providing aquatic plants and freshwater snails" in the ecological culture of $E$. sinensis.

\section{Background}

Chinese mitten crab (Eriocheir sinensis), is an important economic aquaculture species in China (1). The planting of aquatic plants has become one of the key factors for the success of $E$. sinensis culture. Aquatic plants can not only regulate the $\mathrm{pH}$ of water and provide shelter to $E$. sinensis, but also they can be used as food sources by $E$. sinensis due to their rich nutrient contents $(2,3)$. Researchers have indicated that aquatic plants are beneficial for the growth of $E$. sinensis and can improve the nutritional quality of the edible parts of $E$. sinensis. E. sinensis ingest a certain number of aquatic plants to meet their nutritional needs even when receiving sufficient feed (4). Freshwater snails are a high-quality natural feed for $E$. sinensis, and snail feeding in the aquaculture practice can increase the yield and improve the quality of $\operatorname{E}$. sinensis $(5,6)$. Moreover, snails, as an animal-type feed, can increase the content of animal protein in the daily diet, which has a positive influence on the growth of $E$. sinensis (7).

The growth and development of organisms are closely related to the daily food sources. Different food sources cause dramatic changes in the composition of functional proteins in tissues and organs, such as the digestive and metabolic organs; affect biological processes, such as digestion and absorption, energy metabolism, and immune response; and further affect the growth and development of organisms $(8,9)$. Comparing the liver proteomes of rats fed with animal protein with those of rats fed with plant protein revealed the two groups exhibited drastic changes in their protein expression profiles and considerably 
difference on amino acid and fatty acid metabolism (10). The content of proteins related to lipid, carbohydrate, and amino acid metabolism changed in the livers of Oreochromis niloticus fed with daily diets containing different nutrients, and the immune systems of the experimental organisms was also affected (11). Replacing dietary fish oil with linseed oil, resulted in considerable changes in the protein expression profile in the hepatopancreas of $E$. sinensis, and subsequently, the capability of $E$. sinensis to adapt to the environment was also altered (12). Food sources can obviously affect the protein composition of organisms and then further affect the growth and development of organisms. Aquatic plants and freshwater snails, as two kinds of important natural food, play important roles in the growth and development of $E$. sinensis. However, research on how aquatic plants and snails affect the growth and development of $E$. sinensis remains scant.

A comprehensive analysis of the composition and dynamics of functional proteins offers important insights into the roles of aquatic plants and snails in the aquaculture practice of $E$. sinensis. Therefore, in this study, three diverse feed types were provided as daily diets for $E$. sinensis: freshwater snail (Sinotaia quadrata); waterweed plants (Elodea canadensis); and a mixed diet of S. quadrata and E. canadensis. Then, the protein profiles of $E$. sinensis under the three different feed types were determined and compared to investigate the effect of aquatic plants and snails on the growth and development of $E$. sinensis.

\section{Methods}

\section{Sample collection and ethics statement}

Juvenile $E$. sinensis (approximately $7.5 \mathrm{~g}$ ) with the same growth conditions were collected from the Aquatic Animal Germplasm Resource Station of Shanghai Ocean University (Shanghai, China). They were cultured in a circulating water system for seven days to adapt to the environment. Then, the $E$. sinensis individuals were randomly divided into three groups and fed as follows: Group A was fed with a mixed diet of $S$. quadrita and E. canadensis, group B was fed with E. canadensis only, and group C was fed with $S$. quadrita only. All the $E$. sinensis individuals were reared in the circulating water system, named "Crab Dragon Palace" to maintain consistent culture environment. The water temperature was maintained at $26^{\circ} \mathrm{C} \pm 2{ }^{\circ} \mathrm{C}$, and the three groups were fed with abundant food at 9:00 and 16:00 every day, respectively. When the $E$. sinensis grew to the prestage of molting, their hepatopancreas tissues were collected. Three biological replicateswere collected for each group. Then, the tissues were quickly frozen in liquid nitrogen and stored in a $-80{ }^{\circ} \mathrm{C}$ refrigerator. The study was approved by the Institutional Animal Care and Use Committee of Shanghai Ocean University (Shanghai, China). Sampling procedures complied with the guidelines of the Institutional Animal Care and Use Committee on the care and use of animals for scientific purposes.

\section{Protein extraction and quality control}

The collected hepatopancreatic tissues were taken from $-80^{\circ} \mathrm{C}$ refrigerator and homogenized. Approximately $50 \mathrm{mg}$ of minced tissue was mixed with $500 \mu \mathrm{l}$ of RIPA lysate (PMSF was added before use). Subsequently, the homogenate was incubated on an ice bath for $30 \mathrm{~min}$. Centrifugation was performed at $14000 \mathrm{~g}$ for $10 \mathrm{~min}$ at $4{ }^{\circ} \mathrm{Cand}$ the supernatant was collected. Protein concentration was measured with a 
Pierce BCA protein assay kit in accordance with instructions (Thermo fisher, USA), and protein quality was evaluated through SDS-PAGE gel electrophoresis.

\section{Protein alkylation, trypsin enzymatic hydrolysis, and TMT tagging}

The proteins were alkylated in accordance with Randall's protocol (13), and the filter-aided proteome preparation method was used for protease hydrolysis (14). The trypsin enzyme was added on the basis of the ratio of protein: enzyme $=40: 1$. The mixture was placed at $37^{\circ} \mathrm{C}$ overnight. Then, the peptides were desalted and lyophilized. A total of $100 \mu \mathrm{g}$ protein was taken from each sample for TMT labeling by using the 10-plex TMT reagent (Thermo fisher, Art.No.90111) according to the manufacturer's instructions. Three biological replicates were sampled for each group. The labeling steps were as follows: First, the TMT reagent was allowed to recover to room temperature. Then, acetonitrile was added to the sample, and the sample was centrifuged at low speed with a vortex. Second, the sample was mixed with TMT reagent, incubated at room temperature for $2 \mathrm{~h}$, and then mixed with hydroxylamine. The mixture was reacted at room temperature for $15 \mathrm{~min}$. Finally, the same amount of labeled substances was mixed in a tube and drained with a vacuum concentrator.

\section{HPLC fractionation and LC-MS/MS analysis}

Polypeptide samples were redissolved with UPLC loading buffer, and a reverse phase C18 column was used to separate the high $\mathrm{pH}$ liquid phase. A total of 20 fractions were collected and merged into 10 fractions in accordance with peak type and time. After vacuum centrifugation and concentration, the mass spectrometry sample was dissolved with the loading buffer solution for mass spectrometry. The mass spectrometry conditions were as follows: The data acquisition software was Thermo Xcalibur 4.0 (Thermo, USA). The chromatographic instrument was Easy NLC 1200 (Thermo, USA), and the mass spectrometer was Q_Exactive HF-X (Thermo, USA). The chromatographic separation time was 120 min, the flow rate was $300 \mathrm{~nL} / \mathrm{min}$, the scanning range of MS was 350-1300 m/z, and the acquisition mode was data-dependent acquisition (DDA).

\section{Bioinformatic analysis}

Proteome Discoverer ${ }^{\mathrm{TM}}$ software 2.4 was used to search the Eubrachyura Uniprot database and our assembled reference transcriptome (15) to identify and quantify proteins. The MS/MS search criteria were as follows: Mass tolerance of 20 ppm for MS and 0.02 Da for MS/MS Tolorance, trypsin as the enzyme with two missed cleavage allowed, carbamido methylation of cysteine and the TMT of N-terminus and lysine side chains of peptides as fixed modification, and methionine oxidation as dynamic modifications, respectively. False discovery rate (FDR) of peptide identification was set as $P \leq 0.01$. A minimum of one unique peptide identification was used to support protein identification. Proteins with fold change (FC) < 0.667 , or $\mathrm{FC}>1.5$, and $P<0.05$ for the FDR were considered as differentially expressed proteins. Pairwise comparison was conducted between every two groups. Differentially expressed proteins were subjected to Gene Ontology (GO) and Kyoto Encyclopedia of Genes and Genomes (KEGG) enrichment analysis by using the software implemented in Majorbio I-Sanger Cloud Platform with corrected $P<0.05$. 


\section{Results}

\section{Overview of total identified proteins}

After submitting the original data file of the mass spectrometer off machine to the Proteome Discoverer server, 358,336 secondary spectra were obtained, 67,127 spectra were matched, 24,744 peptide fragments, and 9,959 proteins were identified (Fig. 1A). Most identified protein contained less than 23 peptides (Fig. 1B). The protein molecular weight was mainly ranged from 1-80 kDa (Fig. 1C). The error distribution between the real value and the theoretical value of the relative molecular weight of all matched peptides was shown in figure 1D. After the functional annotation of the identified proteins, 4,277 annotated proteins were obtained. Among these proteins, 2,532 proteins were annotated by GO database, accounting for $59.2 \%$ of the total annotated proteins, and 3,041 were annotated by KEGG database accounting for $71.1 \%$ of the total annotated proteins (Table 1).

\section{Bioinformatic analysis of differentially expressed proteins}

The hepatopancreatic proteomics of the three groups were compared and analyzed. A total of 323 differentially expressed proteins were identified with the statistical thresholds of $P<0.05, \mathrm{FC}>1.5$, or FC $<$ 0.67. Compared with those in group $B, 78$ proteins were upregulated, and 32 proteins were downregulated in group A (Fig. 2, Table S1). Compared with those in group C, nine were upregulated and 14 were downregulated in group A (Fig. 2, Table S2). There were 190 differentially expressed proteins between groups $B$ and $C$, and 139 were upregulated and 51 were downregulated in group C (Table S3).

GO enrichment analysis indicated that the differentially expressed proteins between groups A and B were mainly enriched in hydrolase activity, deacetylation, lipoprotein metabolism, and galactosidase activity (Fig. 3, Table S4). The differentially expressed proteins between groups $A$ and $C$ were mainly enriched in oxidative stress reaction and amino acid metabolism (Fig. 3, Table S5). The differentially expressed proteins between groups $\mathrm{B}$ and $\mathrm{C}$ were mainly enriched in protein modification and hydrolase activity (Fig. S1, Table S6). KEGG database was used to analyze the enrichment of differentially expressed proteins in metabolic pathways. The results showed that the differentially expressed proteins between groups $A$ and $B$ were mainly enriched in lysosomes, sphingolipid metabolism, and polysaccharide degradation pathways (Fig. 4, Table S7), whereas the differentially expressed proteins between groups A and C were mainly enriched in metabolic pathways related to infection (Fig. 4, Table S8). The differentially expressed proteins between groups $\mathrm{B}$ and $\mathrm{C}$ were mainly enriched in lysosome, homologous and $\mathrm{N}$-glycan biosynthesis pathway (Table S9, Fig. S2)

\section{Differentially expression proteins between groups}

The proteomes of groups A and B were compared and analyzed. The proteins that were upregulated in group A included cryptocyanin, cuticle protein, solute carrier family 35 member F6, programmed cell death protein, fibroblast growth factor receptor 3. The downregulated proteins in group A were ataxin-2, metalloreductase, pancreatic lipase-related protein 2, and arylsulfatase A (Table 2). The proteomes of groups A and C were also compared and analyzed. Mannosyl oligosaccharide glucosidase, glutathione 
peroxidase 2, calreticulin were among the proteins that were upregulated in group A relative to group $\mathrm{C}$. The proteins that were downregulated in group A were myosin and Rho-associated protein kinase 2 (Table 3 ).

\section{Discussion}

Aquatic plants and freshwater snails are important natural food sources for $E$. sinensis and have a direct effect on the growth and development of $E$. sinensis $(16,17)$. This study was conducted to investigate the differences in the hepatopancreatic proteomes of $E$. sinensis under three different feeding methods: aquatic plants combined with freshwater snails (group A), aquatic plants only (group B), and freshwater snails only (group C). The results showed differences in the protein expression profiles in the hepatopancreas of $E$. sinensis among the three groups. Meanwhile, our previous study has indicated that the weight gain rate and shell length gain rate was highest in group $A$ than in the other two groups $(P<0.05)$, and lower condition factor and hepatopancreas index were identified in group $B$ than groups $A$ and $C(18)$. Together, this study indicated different feed types may alter the proteome of hepatopancreas and affect the growth and development of E. sinensis.

Among the differentially expressed proteins between groups $A$ and $B$, the proteins with high expression levels and the most significant differences in group A were cryptocyanin and cuticle protein CBM. Cryptocyanin is an important member of the hemocyanin gene family and a crustacean molting protein that is closely related to molting and plays an important role in new exoskeleton formation after molting (19, 20). Cuticle proteins are essential component of the exoskeleton of crustacean species. During molting period, the old epidermis falls off, and a new epidermis will be formed in pre-molt stage. Cuticle protein plays a vital role in the formation of the epidermis during molting (21). Cryptocyanin and cuticle protein expression levels were significantly higher in $E$. sinensis fed with aquatic plants and freshwater snails than in those fed with aquatic plants only, indicating that the molting frequency of $E$. sinensis fed with aquatic plants and freshwater snails might be accelerated; this result was also consistent with our previous research results showing that the molting rate of $E$. sinensis fed with aquatic plants and freshwater snails is significantly faster than that of $E$. sinensis fed with aquatic plants only (18). The results of this study showed that the addition of snails to the daily diets of $E$. sinensis could affect the expression of moltingrelated proteins and further affect the moltingprocess. A large number of proteins related to cell proliferation and growth were highly expressed in E. sinensis fed with aquatic plants and freshwater snails; these proteins included solute carrier family 35 member F6 $(22)$, programmed cell death protein $2(23,24)$, and UCN-45 protein homolog A (25) (Table 2). The high expression of these proteins leads to the increase in cell number and volume and further affects the growth and development of $E$. sinensis. Therefore, $E$. sinensis fed with aquatic plants and freshwater snails grew significantly faster than $E$. sinensisfed with aquatic plants only as our previous study presented (18).

Among the proteins that were differentially expressed between groups $A$ and $C$, those that were highly expressed in group A were mannosyl oligosaccharide glucosidase, glutathione peroxidase-2, and calreticulin. Mannosyl oligosaccharide glucosidase is involved in the metabolism of mannan oligosaccharides and can improve the immunity in Litopenaeus vannamei $(26,27)$. Glutathione peroxidase plays an important role in immune defense against pathogen infection in invertebrates. Research on 
Haliotis discus, Chlamys farreri, L. vannamei, and Fenneropenaeus chinensis has shown that glutathione peroxidase is involved in the immune regulation process (28-31). Calreticulin is a highly conserved calcium binding protein, which is an immune-related protein in vertebrates and invertebrates. Studies on Patinopecten yessoensis, Sebastes schlegeli, and Tilapia niloticus all showed that calreticulin is involved in immune regulation (32-34). The levels of these proteins were higher in $E$. sinensis fed with aquatic plants and freshwater snails than in $E$. sinensis fed with only freshwater snails, suggesting that aquatic plants might affect the immunity of $E$. sinensis. Moreover, these results were consistent with previous results that submerged plants in the diet can enhance the immunity of $E$. sinensis $(35,36)$.

\section{Conclusions}

Diets containing aquatic plants may enhance the immunity of $E$. sinensis, while those containing freshwater snails may promote the growth and molting of $E$. sinensis. A mixed diet containing both aquatic plants and freshwater snails maybe the best choice for $E$. sinensis. The results of this work provide a theoretical basis for the practice of "providing aquatic plants and freshwater snails" in the ecological culture of E. sinensis.

\section{Declarations}

\section{Ethics approval and consent to participate}

The study was approved by the Institutional Animal Care and Use Committee of Shanghai Ocean University (Shanghai, China). Sampling procedures complied with the guidelines of the Institutional Animal Care and Use Committee on the care and use of animals for scientific purposes. Acknowledgements

Not applicable.

\section{Consent for publication}

Not applicable.

\section{Availability of data and materials}

All data used to support the findings of this study are available upon request to the corresponding author. The dataset generated in this study has been deposited in the ProteomeXchange Cosortium ( http://proteomecentral.proteomeexchange.org ) with the dataset identifier px-submisssionPXD023215.

\section{Competing interests}

All authors declare that they have no competing interests.

\section{Funding}

This work was supported by the Shanghai Agriculture Applied Technology Development Program, China (Grant No. G2017-02-08-00-10-F00076), Agriculture Research System of Shanghai, China (Grant No. 
202004).

\section{Authors' contributions}

JW and CHW conceived the original idea of the study; XWC, $\mathrm{XH}, \mathrm{ZHL}$ and DYY performed experiments; JW, and XWC analyzed data; XWC and XH interpreted results; XWC and XH prepared figured and drafted manuscript; JW and CHW edit and revised manuscript. XWC and XH approved final version of manuscript. $\mathrm{XWC}$ and $\mathrm{XH}$ contributed equally to this work.

\section{References}

1. Wang J, Xu P, Zhou G, Li X, Lu Q, Liu X, et al. Genetic Improvement and Breeding Practices for Chinese Mitten Crab, Eriocheir sinensis. J World Aquacult Soc. 2018;49(2):292-301.

2. Wang $\mathrm{H}-\mathrm{J}$, Xu C, Wang $\mathrm{H}-\mathrm{Z}$, Kosten S. Long-term density dependent effects of the Chinese mitten crab (Eriocheir sinensis (H. Milne Edwards, 1854)) on submersed macrophytes. Aquat Bot. 2017;140:84-91.

3. Shi L, Tian T, Shen M, Jin M, Zhang Q, Zhang W, et al. Estimation of the lower practical limit of aquatic plant coverage in intensive Chinese mitten crab (Eriocheir sinensis) rearing ponds using an unmanned aerial vehicle. Aquac Res. 2019;50(9):2316-25.

4. Liu Q, Huang S, Yue W, Chen X, Peng Z, Wang J, et al. Effects of Elodea nuttallii on growth and nutritional quality of Chinese mitten crab, Eriocheir sinensis (in Chinese). Journal of Fishery Sciences of China. 2017;24(01):91-9.

5. Wang H, Jin M, Shen M, Lu C, Shi L, Zhou X, et al. Research on the suitable feeding amount of snails and the effects on the yield and water quality of crab pond (in Chinese). Fisheries Science and Technology Information. 2016;43(01):37-40.

6. Ruan Z, Sun Y. Ecological culture of crab by planting grass and throwing snails (in Chinese). Fishery Guide to be Rich. 2018(09):45-6.

7. Hua $D$, Wen $H, X u G$, Wang $S$. Growth and free amino acids in muscle and liver of Chinese mitten crab (Eriocheir sinensis) fed clam Anodonta woodiana pacifica (in Chinese). Journal of Dalian Fisheries University. 2006(01):83-6.

8. Keyvanshokooh S, Tahmasebi-Kohyani A. Proteome modifications of fingerling rainbow trout (Oncorhynchus mykiss) muscle as an effect of dietary nucleotides. Aquaculture. 2012;324-325:79-84.

9. Morais S, Silva T, Cordeiro O, Rodrigues P, Guy DR, Bron JE, et al. Effects of genotype and dietary fish oil replacement with vegetable oil on the intestinal transcriptome and proteome of Atlantic salmon (Salmo salar). BMC Genomics. 2012;13(1):448.

10. Song S, Hooiveld GJ, Zhang W, Li M, Zhao F, Zhu J, et al. Comparative Proteomics Provides Insights into Metabolic Responses in Rat Liver to Isolated Soy and Meat Proteins. J Proteome Res. 2016;15(4):1135-42.

11. Boonanuntanasarn S, Nakharuthai C, Schrama D, Duangkaew R, Rodrigues PM. Effects of dietary lipid sources on hepatic nutritive contents, fatty acid composition and proteome of Nile tilapia (Oreochromis niloticus). J Proteomics. 2019;192:208-22. 
12. Wei B, Yang Z, Cheng Y, Wang J, Zhou J. Effects of the complete replacement of fish oil with linseed oil on growth, fatty acid composition, and protein expression in the Chinese mitten crab (Eriocheir sinensis). Proteome Sci. 2018;16(1):6.

13. Randall MJ, Hristova M, van der Vliet A. Protein alkylation by the $a, \beta$-unsaturated aldehyde acrolein. A reversible mechanism of electrophile signaling? FEBS Lett. 2013;587(23):3808-14.

14. Wiśniewski JR, Zougman A, Nagaraj N, Mann M. Universal sample preparation method for proteome analysis. Nat Methods. 2009;6(5):359-62.

15. Wang J, Chen X, He F, Song X, Huang S, Yue W, et al. Global Analysis of Gene Expression Profiles Provides Novel Insights into the Development and Evolution of the Large Crustacean Eriocheir sinensis. Genom Proteom Bioinf. 2020.

16. Meng X, Song X, Chen G, Feng Y, Wu L, Shen Z. Utilization of natural feed resources in a macrophytedominated lake for aquaculture of Chinese mitten crab (Eriocheir sinensis) and its purification effects on water environment (in Chinese). Journal of Lake Sciences. 2013;25(05):723-8.

17. Chen W, Zhang M, Zhao J, Cong H. Summary of crab culture experiment in purification area of pond industrialized ecological culture system (in Chinese). Scientific Fish Farming. 2019;12:32-3.

18. Chen X, Lu D, Li Z, Yue W, Wang J, Jiang X, et al. Plant and animal-type feedstuff shape the gut microbiota and metabolic processes of the Chinese mitten crab Eriocheir sinensis. Front.Vet. Sci. 2021;8:19.

19. Terwilliger NB, Dangott L, Ryan M. Cryptocyanin, a crustacean molting protein: Evolutionary link with arthropod hemocyanins and insect hexamerins. P Natl Acad Sci. 1999;96(5):2013.

20. Terwilliger NB. Gene expression profile, protein production, and functions of cryptocyanin during the crustacean molt cycle. Invertebr Reprod Dev. 2012;56(3):229-35.

21. Kuballa AV, Merritt DJ, Elizur A. Gene expression profiling of cuticular proteins across the moult cycle of the crab Portunus pelagicus. BMC Biol. 2007;5(1):45.

22. Kashiwaya K, Hosokawa M, Eguchi H, Ohigashi H, Ishikawa O, Shinomura $Y$, et al. Identification of C2orf18, termed ANT2BP (ANT2-binding protein), as one of the key molecules involved in pancreatic carcinogenesis. Cancer Sci. 2009;100(3):457-64.

23. Kokorina NA, Granier CJ, Zakharkin SO, Davis S, Rabson AB, Sabaawy HE. PDCD2 knockdown inhibits erythroid but not megakaryocytic lineage differentiation of human hematopoietic stem/progenitor cells. Exp Hematol. 2012;40(12):1028-42.e3.

24. Liu Y, Xu H, An M. mTORC1 regulates apoptosis and cell proliferation in pterygium via targeting autophagy and FGFR3. Sci Rep-UK. 2017;7(1):7339.

25. Jilani Y, Lu S, Lei H, Karnitz LM, Chadli A. UNC45A localizes to centrosomes and regulates cancer cell proliferation through ChK1 activation. Cancer Lett. 2015;357(1):114-20.

26. Chen M, Chen X-Q, Tian L-X, Liu Y-J, Niu J. Beneficial impacts on growth, intestinal health, immune responses and ammonia resistance of pacific white shrimp (Litopenaeus vannamei) fed dietary synbiotic (Mannan oligosaccharide and Bacillus licheniformis). Aquacult Rep. 2020;17:100408. 
27. Rungrassamee W, Kingcha Y, Srimarut Y, Maibunkaew S, Karoonuthaisiri N, Visessanguan W. Mannooligosaccharides from copra meal improves survival of the Pacific white shrimp (Litopenaeus vannamei) after exposure to Vibrio harveyi. Aquaculture. 2014;434:403-10.

28. De Zoysa M, Pushpamali WA, Oh C, Whang I, Kim SJ, Lee J. Transcriptional up-regulation of disk abalone selenium dependent glutathione peroxidase by $\mathrm{H} 2 \mathrm{O} 2$ oxidative stress and Vibrio alginolyticus bacterial infection. Fish Shellfish Immunol. 2008;25(4):446-57.

29. Mu C, Ni D, Zhao J, Wang L, Song L, Li L, et al. cDNA cloning and mRNA expression of a seleniumdependent glutathione peroxidase from Zhikong scallop Chlamys farreri. Comp Biochem Physiol B: Biochem Mol Biol. 2010;157(2):182-8.

30. Liu $\mathrm{CH}$, Tseng MC, Cheng W. Identification and cloning of the antioxidant enzyme, glutathione peroxidase, of white shrimp, Litopenaeus vannamei, and its expression following Vibrio alginolyticus infection. Fish Shellfish Immunol. 2007;23(1):34-45.

31. Ren Q, Sun RR, Zhao XF, Wang JX. A selenium-dependent glutathione peroxidase (Se-GPX) and two glutathione S-transferases (GSTs) from Chinese shrimp (Fenneropenaeus chinensis). Comp Biochem Physiol C: Toxicol Pharmacol. 2009;149(4):613-23.

32. Wang G, Jiang Z, Zhang M, Yang N, Zhu D. Identification of a new calreticulin homolog from Yesso scallop (Patinopecten yessoensis) and its role in innate immunity. Fish Shellfish Immunol. 2016;58:108-15.

33. Yin $\mathrm{X}, \mathrm{Wu} \mathrm{H}, \mathrm{Mu} \mathrm{L}, \mathrm{Han} \mathrm{K}, \mathrm{Xu} \mathrm{H}$, Jian J, et al. Identification and characterization of calreticulin (CRT) from Nile tilapia (Oreochromis niloticus) in response to bacterial infection. Aquaculture. 2020;529:735706.

34. Wang GH, Li ZX, Guo EM, Wang JJ, Zhang M, Hu YH. A novel calreticulin-related molecule that interacts with bacteria and enhances host resistance against bacterial infection in black rockfish, Sebastes schlegeli. Fish Shellfish Immunol. 2019;93:823-31.

35. Sun L, Song X, Zhu J, Meng X, Zhang L. Effects of submerged plants on growth performance and nonspecific immunity of Chinese mitten crab (Eriocheir sinensis) (in Chinese). Freshwater Fisheries. 2012;42(01):35-40.

36. Sun L. Assessment of common submerged macrophytes in East Taihu Lake as feed resources for Eriocheir sinensis. 2011. Thesis, Suzhou University.

\section{Tables}

Table1. The information of identified protein with annotation based on different database. 


\begin{tabular}{|lll|}
\hline Databases & Number of proteins & Percentage \\
\hline SubCell-Location & 4277 & 1 \\
\hline COG & 1481 & 0.3463 \\
\hline KEGG & 3041 & 0.711 \\
\hline GO & 2532 & 0.592 \\
\hline Pfam & 3844 & 0.8988 \\
\hline Total & 4277 & 1 \\
\hline
\end{tabular}

Percentage: Ratio of number of annotated proteins to the total number of proteins.

Table 2. Important differentially expressed proteins between the hepatopancreas of $E$. sinensis in group A fed with $E$. canadensis and $S$. quadrata and in group B fed with $E$. canadensis only $(P<0.05, \mathrm{FC}<0.67$, or $\mathrm{FC}>1.5$,). 


\begin{tabular}{|c|c|c|c|c|c|c|}
\hline $\begin{array}{l}\text { Accession/ } \\
\text { Uniprot }\end{array}$ & Protein & $P$ value & 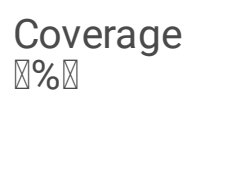 & $\begin{array}{l}\text { No. of } \\
\text { peptides }\end{array}$ & $\begin{array}{l}\text { Fold } \\
\text { change } \\
\text { A/B }\end{array}$ & $\begin{array}{l}\text { Related } \\
\text { Function }\end{array}$ \\
\hline A0A223G1B9 & $\begin{array}{l}\text { Putative } \\
\text { hemocyanin }\end{array}$ & 0.002733 & 16.00587 & 3 & 3.83 & $\begin{array}{l}\text { Molt and } \\
\text { growth }\end{array}$ \\
\hline 096992 & $\begin{array}{l}\text { Putative } \\
\text { hemocyanin }\end{array}$ & 0.02816 & 23.583461 & 1 & 6.67 & $\begin{array}{l}\text { Molt and } \\
\text { growth }\end{array}$ \\
\hline A1YLE8 & $\begin{array}{l}\text { Cuticle protein } \\
\text { CBM }\end{array}$ & 0.02132 & 16.51376 & 1 & 2.26 & Cuticle \\
\hline Q8N357 & $\begin{array}{l}\text { Solute carrier } \\
\text { family } 35 \text { member } \\
\text { F6 }\end{array}$ & 0.04072 & 1.745636 & 1 & 1.70 & $\begin{array}{l}\text { Cell } \\
\text { proliferation }\end{array}$ \\
\hline P47816 & $\begin{array}{l}\text { Programmed cell } \\
\text { death protein } 2\end{array}$ & 0.002475 & 8.241758 & 3 & 1.77 & $\begin{array}{l}\text { Cell } \\
\text { proliferation }\end{array}$ \\
\hline Q99KD5 & $\begin{array}{l}\text { Protein unc-45 } \\
\text { homolog A }\end{array}$ & 0.04481 & 1.740812 & 1 & 1.73 & $\begin{array}{l}\text { Cell } \\
\text { proliferation }\end{array}$ \\
\hline 000571 & $\begin{array}{l}\text { ATP-dependent } \\
\text { RNA helicase } \\
\text { DDX3X }\end{array}$ & 0.01342 & 16.19813 & 11 & 1.51 & Cell growth \\
\hline Q14678 & $\begin{array}{l}\text { KN motif and } \\
\text { ankyrin repeat } \\
\text { domain-containing } \\
\text { protein } 1\end{array}$ & 0.001738 & 2.578797 & 1 & 1.50 & $\begin{array}{l}\text { Cell } \\
\text { proliferation }\end{array}$ \\
\hline Q6NX65 & $\begin{array}{l}\text { Programmed cell } \\
\text { death protein } 10\end{array}$ & 0.04888 & 4.587156 & 1 & 1.76 & $\begin{array}{l}\text { Cell } \\
\text { proliferation }\end{array}$ \\
\hline 070305 & Ataxin-2 & 0.02852 & 0.64695 & 1 & 0.46 & $\begin{array}{l}\text { Negative } \\
\text { regulation of } \\
\text { growth }\end{array}$ \\
\hline Q687X5 & Metalloreductase & 0.00888 & 1.520913 & 1 & 0.64 & $\begin{array}{l}\text { Negative } \\
\text { regulation of } \\
\text { cell } \\
\text { proliferation }\end{array}$ \\
\hline P12617 & $\begin{array}{l}\text { Malonyl-CoA } \\
\text { decarboxylase }\end{array}$ & 0.0351 & 1.666667 & 1 & 1.60 & $\begin{array}{l}\text { Lipid } \\
\text { synthesis }\end{array}$ \\
\hline Q99JB2 & $\begin{array}{l}\text { Stomatin-like } \\
\text { protein } 2\end{array}$ & 0.009692 & 26.36986 & 3 & 1.62 & $\begin{array}{l}\text { Lipid } \\
\text { localization }\end{array}$ \\
\hline A0A0P4VPE9 & $\begin{array}{l}\text { FABP domain- } \\
\text { containing protein }\end{array}$ & 0.03487 & 11.19403 & 1 & 1.58 & Lipid binding \\
\hline Q9NUQ2 & $\begin{array}{l}\text { 1-acyl-sn-glycerol- } \\
\text { 3-phosphate } \\
\text { acyltransferase } \\
\text { epsilon }\end{array}$ & 0.04965 & 1.715686 & 1 & 1.50 & $\begin{array}{l}\text { Phospholipid } \\
\text { synthesis }\end{array}$ \\
\hline P57093 & Phytanoyl-CoA & 0.01746 & 17.64706 & 1 & 1.65 & Lipid \\
\hline
\end{tabular}




\begin{tabular}{|c|c|c|c|c|c|c|}
\hline & dioxygenase & & & & & metabolism \\
\hline Q91XV4 & $\begin{array}{l}\text { L-xylulose } \\
\text { reductase }\end{array}$ & 0.006572 & 70.78189 & 13 & 0.60 & $\begin{array}{l}\text { Carbohydrate } \\
\text { metabolism }\end{array}$ \\
\hline Q95327 & $\beta$-mannosidase & 0.04392 & 5.925926 & 1 & 0.47 & $\begin{array}{l}\text { Carbohydrate } \\
\text { metabolism }\end{array}$ \\
\hline P54318 & $\begin{array}{l}\text { Pancreatic lipase- } \\
\text { related protein } 2\end{array}$ & 0.03813 & 14.72393 & 2 & 0.32 & $\begin{array}{l}\text { Nutrition } \\
\text { response }\end{array}$ \\
\hline P50428 & Arylsulfatase A & 0.0166 & 10.91703 & 2 & 0.58 & $\begin{array}{l}\text { Nutrition } \\
\text { response }\end{array}$ \\
\hline P10768 & $\begin{array}{l}\text { S- } \\
\text { formylglutathione } \\
\text { hydrolase }\end{array}$ & 0.005636 & 42.76923 & 12 & 1.78 & $\begin{array}{l}\text { Thiolester } \\
\text { hydrolase } \\
\text { activity }\end{array}$ \\
\hline K7IXU0 & $\begin{array}{l}\text { Palmitoyl-protein } \\
\text { hydrolase } 1\end{array}$ & 0.01932 & 20.80537 & 2 & 0.66 & $\begin{array}{l}\text { Lipoprotein } \\
\text { metabolic } \\
\text { process }\end{array}$ \\
\hline Q9TRY9 & Beta-galactosidase & 0.02479 & 43.94905 & 4 & 0.64 & $\begin{array}{l}\text { Beta- } \\
\text { galactosidase } \\
\text { activity }\end{array}$ \\
\hline A0A0P4WEX6 & $\begin{array}{l}\text { Palmitoyl-protein } \\
\text { hydrolase } 1\end{array}$ & 0.04374 & 9.666667 & 1 & 0.48 & $\begin{array}{l}\text { Protein } \\
\text { deacylation }\end{array}$ \\
\hline
\end{tabular}

Table 3. Important differentially expressed proteins between the hepatopancreas of $E$. sinensis in group A fed with E. canadensis and $S$. quadrata and group C fed with $S$. quadrata only $(P<0.05, \mathrm{FC}<0.67$, or $\mathrm{FC}>$ 1.5, ). 


\begin{tabular}{|c|c|c|c|c|c|c|}
\hline $\begin{array}{l}\text { Accession/ } \\
\text { Uniprot }\end{array}$ & Protein & $P$ value & $\begin{array}{l}\text { Coverage } \\
\varangle \% \square\end{array}$ & $\begin{array}{l}\text { No. of } \\
\text { peptides }\end{array}$ & $\begin{array}{l}\text { Fold } \\
\text { change } \\
\mathrm{A} / \mathrm{C}\end{array}$ & Related Function \\
\hline Q80UM7 & $\begin{array}{l}\text { Mannosyl- } \\
\text { oligosaccharide } \\
\text { glucosidase }\end{array}$ & 0.02686 & 17.01031 & 1 & 1.52 & Immune \\
\hline Q4AEI0 & $\begin{array}{l}\text { Glutathione } \\
\text { peroxidase } 2\end{array}$ & 0.0428 & 35.50725 & 3 & 1.62 & $\begin{array}{l}\text { Immune/Response } \\
\text { to oxidative stress }\end{array}$ \\
\hline A0A193DUV8 & Calreticulin & 0.01644 & 67.9803 & 2 & 4.50 & Immune \\
\hline P05661 & $\begin{array}{l}\text { Myosin heavy } \\
\text { chain }\end{array}$ & 0.04912 & 3.655352 & 1 & 0.61 & $\begin{array}{l}\text { Muscle } \\
\text { contraction }\end{array}$ \\
\hline МЗТYТО & $\begin{array}{l}\text { Rho-associated } \\
\text { protein kinase } 2\end{array}$ & 0.01186 & 1.763409 & 2 & 0.64 & $\begin{array}{l}\text { Muscle } \\
\text { contraction }\end{array}$ \\
\hline 043396 & $\begin{array}{l}\text { Thioredoxin-like } \\
\text { protein } 1\end{array}$ & 0.002447 & 29.67033 & 5 & 0.55 & $\begin{array}{l}\text { Response to } \\
\text { oxidative stress }\end{array}$ \\
\hline Q6NWZ9 & $\begin{array}{l}\text { Cysteine } \\
\text { dioxygenase } \\
\text { type } 1\end{array}$ & 0.03732 & 16.74641 & 4 & 0.56 & $\begin{array}{l}\text { L-cysteine } \\
\text { metabolic process }\end{array}$ \\
\hline
\end{tabular}

\section{Figures}
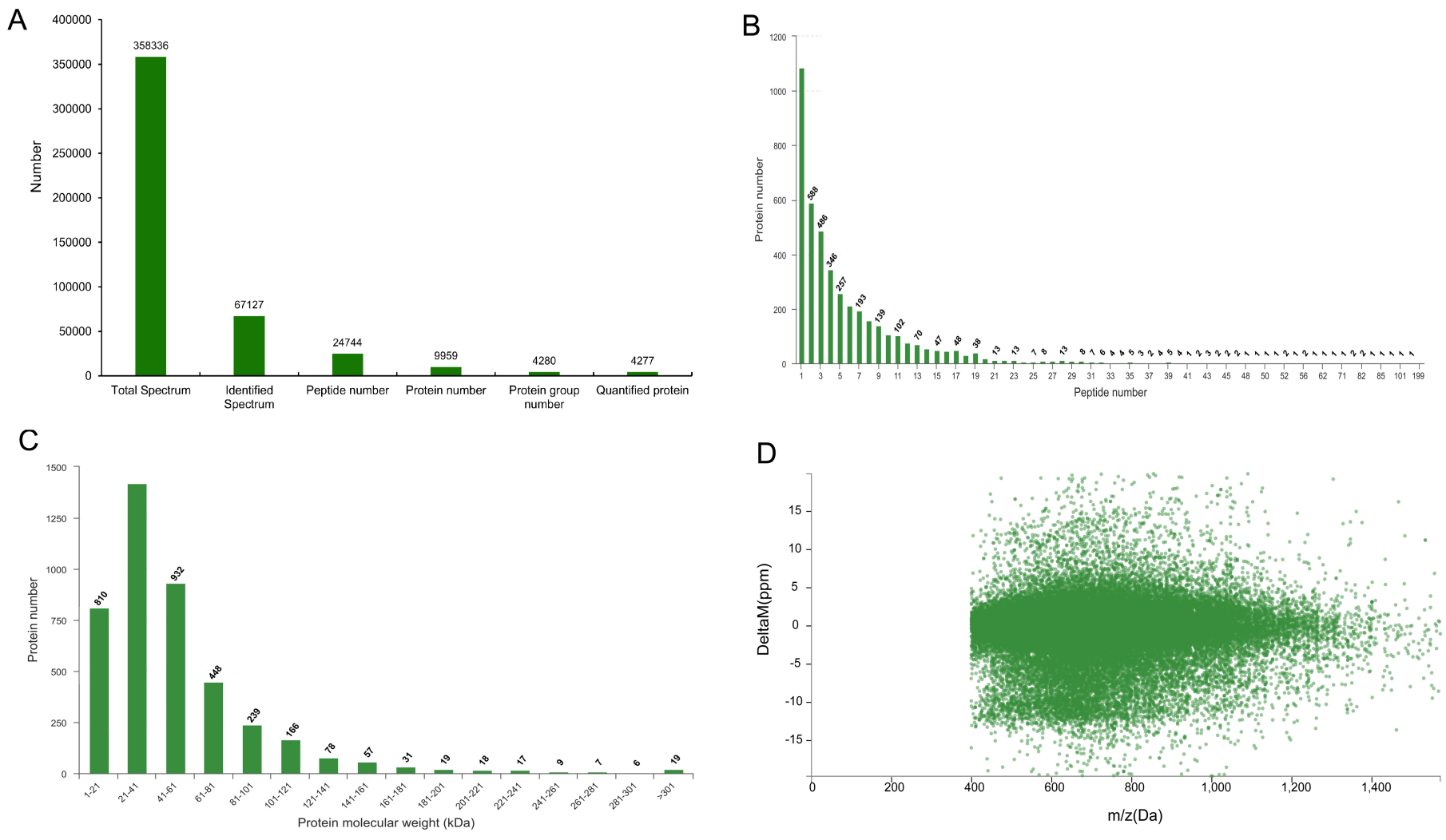

Figure 1 
Statistical data of reliable peptides in hepatopancreas samples of E. sinensis. A. The distribution of peptide matching error. B. The distribution of peptide number. C. The distribution of protein molecular weight. D. The number of proteins.

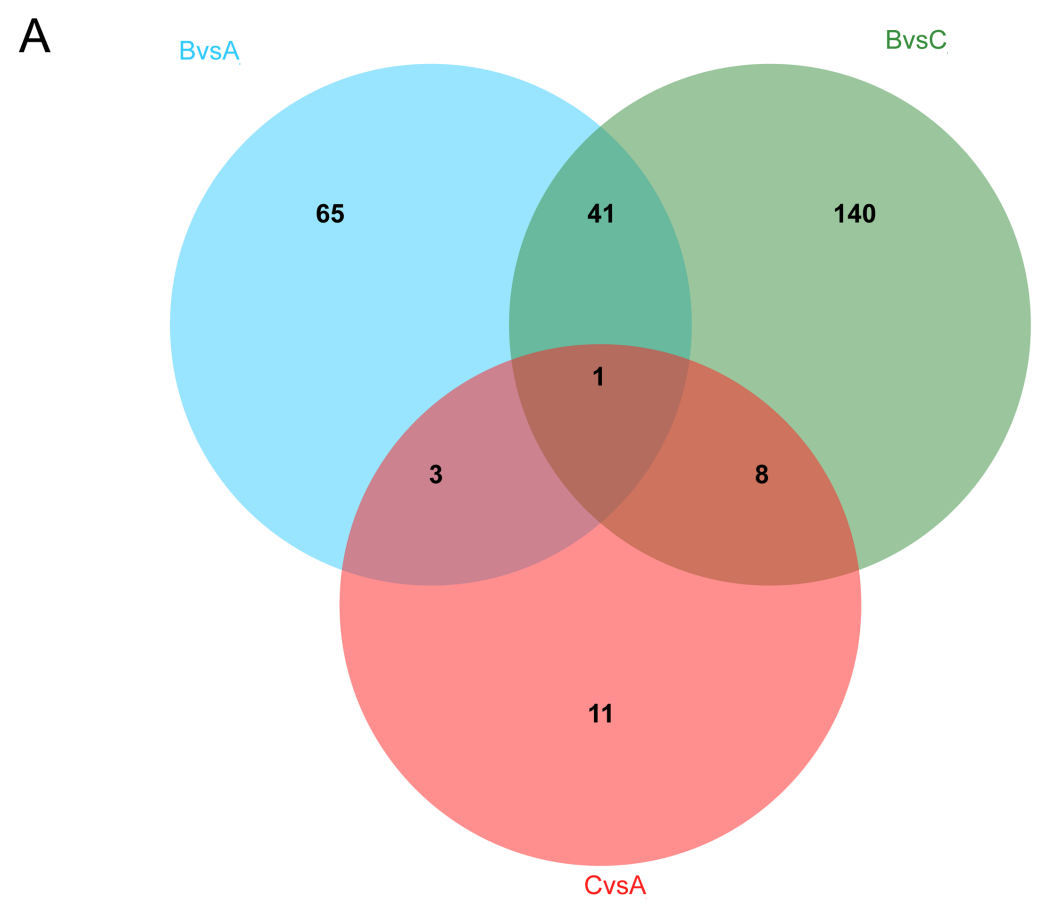

B

B vs A

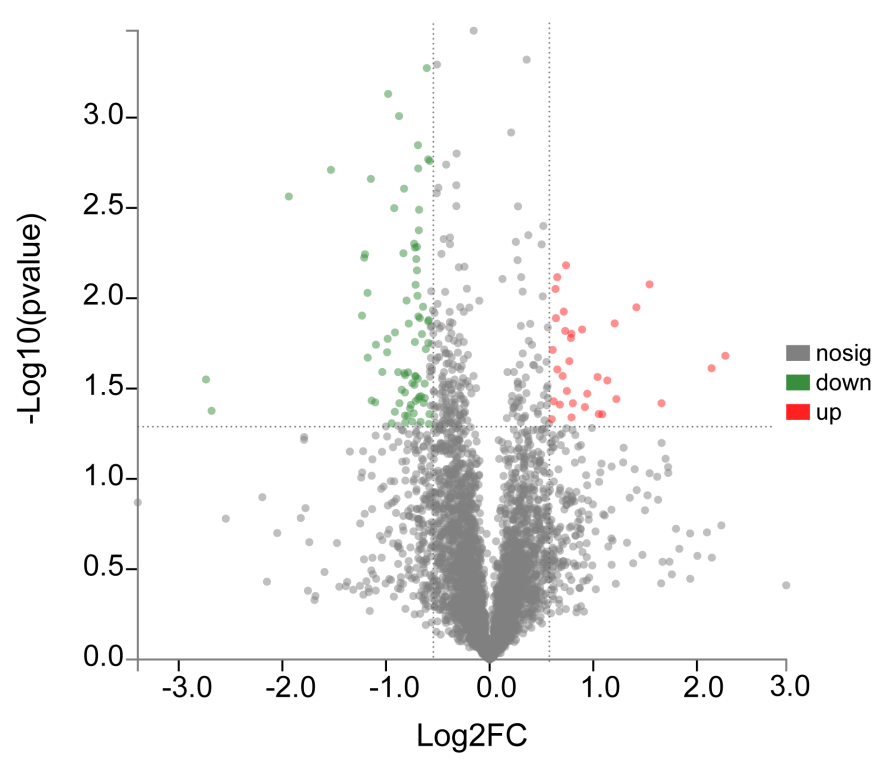

Cvs A

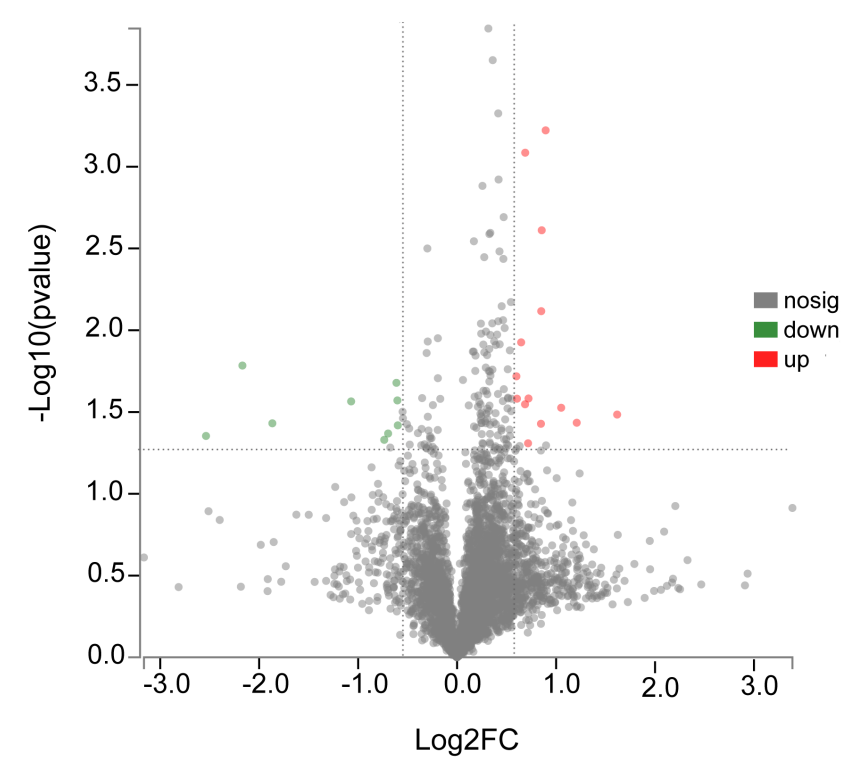

\section{Figure 2}

The display of differentially expressed genes. A. Venn diagram of differentially expressed genes between groups. B. Volcano map of differentially expressed proteins between groups. $P<0.05$, Fold change $>1.5$ or $<0.67$. The green means down-regulated proteins and red means up-regulated proteins. 

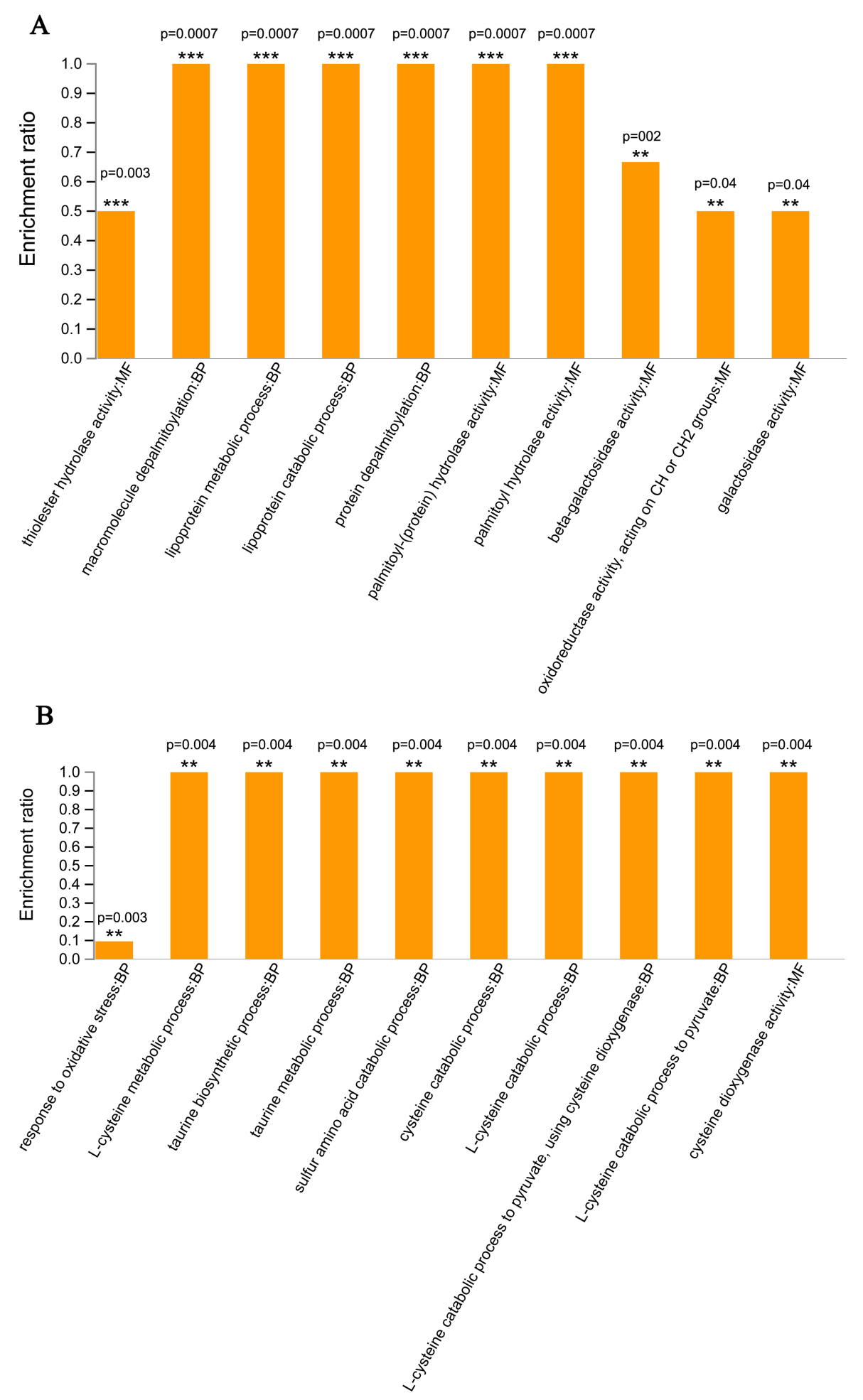

\section{Figure 3}

Gene ontology (GO) annotation of differential expressed proteins between groups $A$ and $B(A)$ and between groups $A$ and $C(B)$. Note: ** $P<0.001, * \star P<0.01, * P<0.05$. 
A

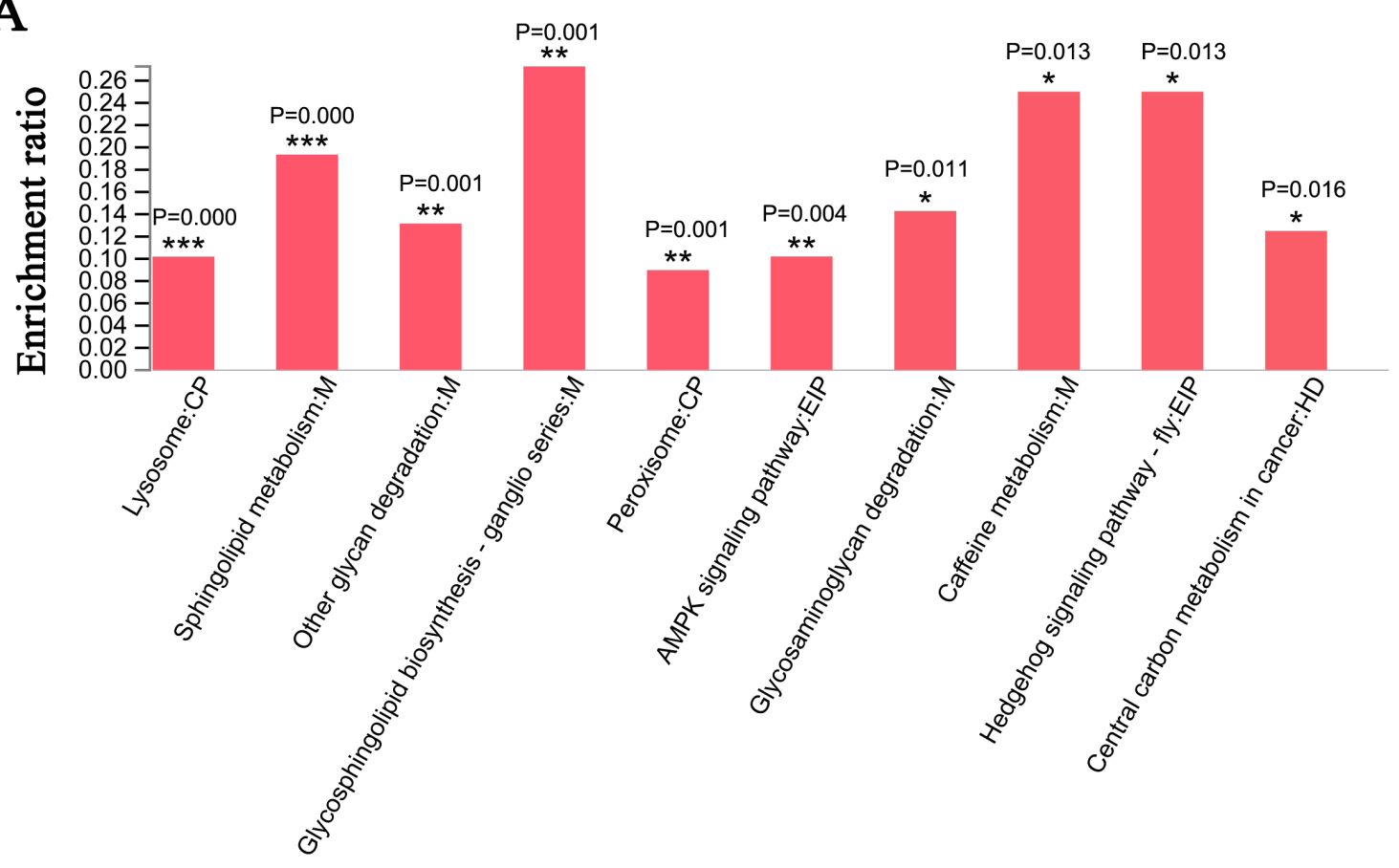

B

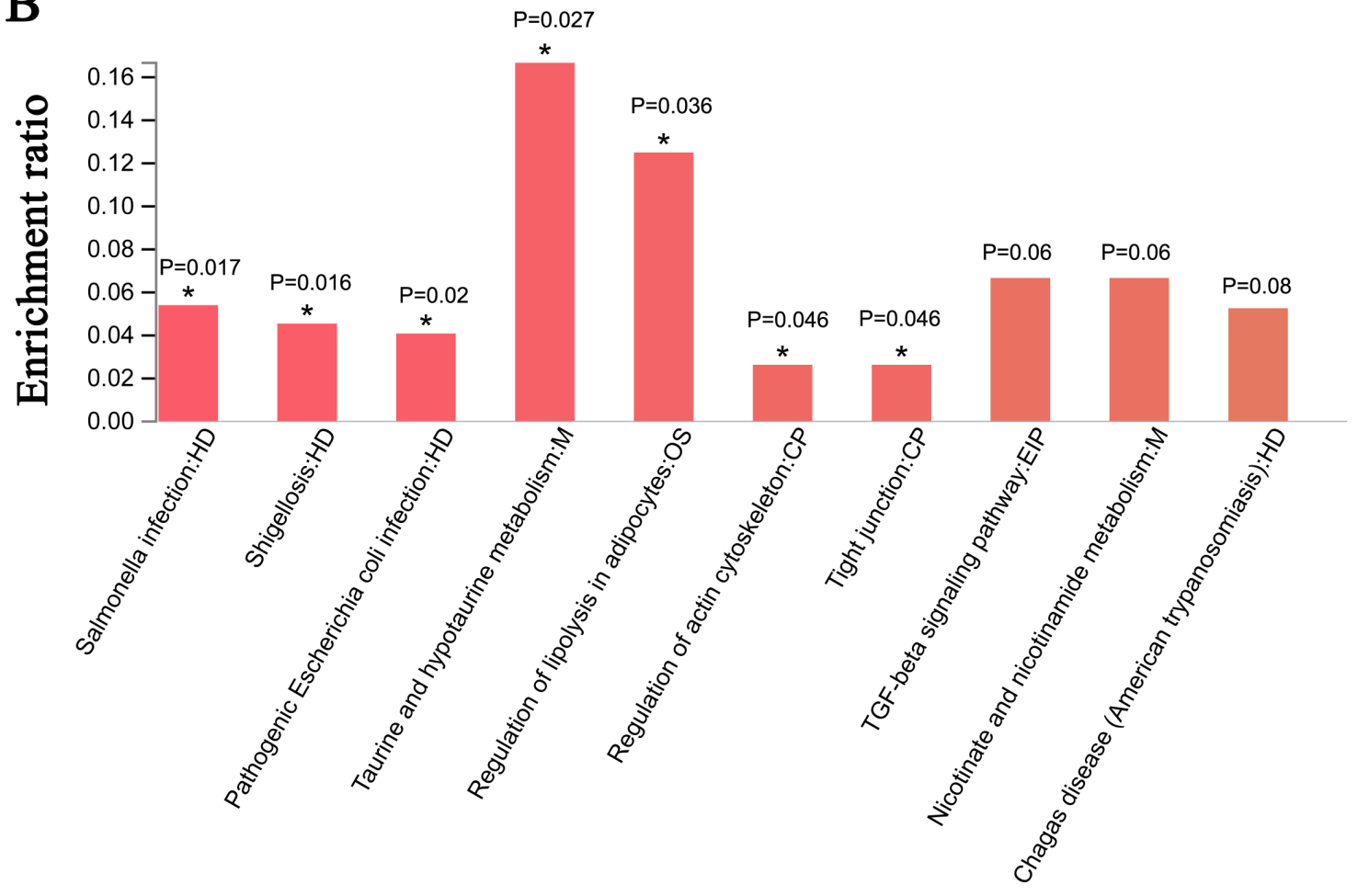

Figure 4

KEGG pathway enrichment analysis of differential expressed proteins between groups $A$ and $B(A)$ and between groups $A$ and $C(B)$. Note: ${ }^{* \star} P<0.001, * \star P<0.01, * P<0.05$.

\section{Supplementary Files}

This is a list of supplementary files associated with this preprint. Click to download. 
- Tables1.xls

- Tables2.xls

- Tables3.xls

- TableS4.xls

- Tables5.xls

- TableS6.xls

- Tables7.xls

- Tables8.xls

- Figures1.tif

- Figures2.tif 